Newfoundland and Labrador Studies

\title{
Violet Drake, Daze Jefferies, Fionn Shea, Perin Squires, Taylor Stocks, Dane Woodland, with dramatic text by Berni Stapleton and Sharon King-Campbell. transVersing
}

\section{Alex Fallis}

Volume 34, Number 2, 2019

URI: https://id.erudit.org/iderudit/1072657ar

DOI: https://doi.org/10.7202/1072657ar

See table of contents

Publisher(s)

Faculty of Arts, Memorial University

ISSN

1719-1726 (print)

1715-1430 (digital)

Explore this journal

\section{Cite this review}

Fallis, A. (2019). Review of [Violet Drake, Daze Jefferies, Fionn Shea, Perin Squires, Taylor Stocks, Dane Woodland, with dramatic text by Berni Stapleton and Sharon King-Campbell. transVersing]. Newfoundland and Labrador Studies, 34(2), 333-336. https://doi.org/10.7202/1072657ar 
Violet Drake, Daze Jefferies, Fionn Shea, Perin Squires, Taylor

Stocks, Dane Woodland, with dramatic text by Berni Stapleton and Sharon King-Campbell. transVersing. St. John's: Breakwater Books, 2018. ISBN 978-1-550-81762-1

transVersing is a unique and powerful addition to the literature of Newfoundland and Labrador. Published in 2018, it is the result of a collaboration between For the Love of Learning ("a St. John's based charity that provides at-risk youth with arts-based training") and theatre company Artistic Fraud of Newfoundland. The first part of the book is made up of the individual contributions of six transgendered people from Newfoundland. This writing is in a number of forms, including personal memoir, poetry, and song lyrics. The second part, organized by theatre artists Berni Stapleton and Sharon King-Campbell, weaves the individual contributions into a dramatic text that has been performed in numerous venues.

Given that the book is made up of the contributions of many people, and in a variety of forms, in some ways there is no overarching artistic shape. For example, it appears that the individual contributions are ordered alphabetically, without an attempt to develop a particular aesthetic, form, or perspective. However, when the reader reaches the dramatic text, all the earlier material is seen in a new light, where commonalities and shared themes are seen, regardless of artistic form. In this way, the book creates a unique diversity of perspectives. First, the individual voices are clear and unmistakably their own. Then, in the dramatic text, a sense of community arises as the different personalities come together through the interweaving of their texts. This combination of individual and then communal perspectives is one of the great strengths of the book, and gives it a visceral and unique power.

In the first part of the book we have the individual contributions of the six transgendered persons. (Note: gender pronouns throughout follow the pronouns used in the contributors' biographies.) Violet Drake writes very lyric and personal poetry. Her work is quite introspective, with short lines and some interesting wordplay. For example, 
her poem "Bookworm" describes reading as "a place where / I / eye / could be / anywhere (else).” Daze Jefferies also writes poetry, though with an even stronger sense of how words are presented on the page. Particularly the poem "Blowmedown" has a wonderful graphic quality that enhances its meaning. This poem also has a strong sense of being both at home and out of place in rural Newfoundland as it references "nanny and poppy's place," and having "dogberries / flung / at me ... by lawless / boys / with / missing / teeth."

Fionn Shea has two prose pieces (titled "Iterations") and one poem. They also include a famous monologue from Shakespeare's King Lear as another "Iteration." Shakespeare provides a kind of solace for Shea, as they relate a lovely story of how they "came out as queer in the middle of As You Like It." The outsider quality of characters like Richard III and Edmund (the speaker of the monologue from King Lear) also has important resonance for them. Perhaps drawing on the declamatory power of the fictional characters, the writing, while personal, has a stronger oratorical and political tone than the earlier writers, especially when Shea contemplates moving to the US.

Perin Squires contributes only one piece (which is not in the theatre text). It is in the form of personal memoir. It tells a powerful story about finding a space in the "not flattering," "neutral" uniform of the army cadets, and the strong family reaction to a young person cutting off their "blonde ringlets."

The contributions of Taylor Stocks include song lyrics and poetry. As a result, their work has more stylistic variety. The lyrics for the song "Trans Life on the Rock" add a welcome note of humour to the collection. They also include two poems (not a part of the dramatic text) about the lure of trying to fit into wider mainstream society - "Invite Me" and "The Promise Call," which concludes, "How could I resist the promise of such protection?"

Dane Woodland's work concludes the individual contributions. Woodland has a TED Talk online that has received over 33,000 views, and his work here is very much in that style. He writes a series of reflections on "Adages" - very direct, clear expression. He also contributes 
one poem, "Fascination," which asks the question "What is this fascination / With the bodies of people / Who are trans."

As is often the case in plays created from writing that comes from numerous authors, the performance text that follows the individual sections has the quality of a collage, with short sections from the earlier pieces folded together. There is no dialogue between the performers, and there are no "scenes" in the traditional theatrical sense. The text has no overarching narrative and the individual voices are simply set next to the others. Often this serves to reinforce the point made by the other writers/performers, and allows for multiple perspectives to come together into a more communal expression. This is also reflected in the form, as music and song are added, and the different personal styles of the poetry and prose are maintained. Themes arise and are explored through this variety of voices, all directly addressed to the audience.

While there are no distinct scene breaks in the text, for this reader the dramatic text divides into three main sections. In the first, we hear of youth and the realization of "difference"; if I were to give this section a title, it would be Taylor's opening line, "Before I was born ..." This section particularly develops the question of "difference" as having both internal and external aspects. How do people (the audience) see transgendered people? And how do trans people see themselves in the context of the wider world? The material of Violet and Taylor is quite personal, with more inward focus, while Dane and Fionn are more outward-looking. Dane asks questions of the audience, while Fionn challenges them, "I dare you to look at my body and tell me I am deformed."

The second section of the piece allows each writer/performer an uninterrupted personal statement. Taylor begins with a song, which is followed by Dane using his direct, TED talk style of address. Fionn gives the section a political call to action, and Violet continues with poetic storytelling. Some of the performers have more than one piece in this section (including a "letter" from Taylor to their mum which is not in the first section of the book), and each is a strong and individual 
statement. This section allows the audience to see the wide range of personalities in the group.

The text finishes with another section in the collage style. It is framed by Taylor's song "Definitions." Between verses of the song, each of the other performers has a final thought, primarily around the idea of Dane's statement, "This is where I have arrived."

transVersing has much to offer the reader. The variety of forms allows each writer an exceptionally personal mode of expression. Each personality comes through clearly, and we feel directly connected to each of them. Then, the dramatic text allows us to see how the interweaving of individual experience can become the expression of a larger community. The book offers a unique, and beautifully expressed, look into the lives of trans people in Newfoundland and Labrador, as individuals and as a community. And at a time when visibility and acceptance are still challenged, it is important to acknowledge the powerful artistic voices that are a part of the trans community. As Violet Drake states of herself (and I would add, her community),

i reside

on this rock

just as you

and the rest of us do

Alex Fallis

Grenfell Campus, Memorial University of Newfoundland 